\title{
CARPENTRY, JOINERY AND MACHINE WOODWORKING
}

(Wood Trades Part 1)

A. B. Emary

F.B.I.C.C. 
All rights reserved. No reproduction, copy or transmission of this publication may be made without written permission.

First published 1974 by THE MACMILLAN PRESS LTD

London and Basingstoke Associated companies and representatives throughout the world

ISBN 978-1-349-02092-8 ISBN 978-1-349-02090-4 (eBook) DOI 10.1007/978-1-349-02090-4

The paperback edition of this book is sold subject to the condition that it shall not, by way of trade or otherwise, be lent, re-sold, hired out, or otherwise circulated without the publisher's prior consent in any form of binding or cover other than that in which it is published and without a similar condition including this condition being imposed on the subsequent purchaser. 
Carpentry, Joinery and Machine Woodworking

PTF LOW PRICE EDITION 


\section{Contents}

Preface

1 Materials

Conversion of Logs into Boards

The Need for Seasuning

Drying Timber

$$
\text { air seasoning - kiln seasoning }
$$

Defects

identification of defects

Common Defects Affecting Strength knots - shakes, splits and checks

Moisture Content

Common Causes of Decay

Dry Rot

Introduction to Preservation

tar oils - water-borne preservatives - organic solvents

Anplication of Preservatives non-pressure - pressure

Moisture Movement principles of capillarity and surface tension position and function of anti-capillarity grooves, water bars and throatings

Hardwoods and Softwoods

Selection of Timber identification by inspection - sources of supply

Timber Sizes

Adhesives scotch glue - casein adhesive - synthetic resin adhesives

Types of Manufactured Boards laminboard, blockboard and battenboard chipboard - hardboard - fibre insulatingboard

2 Tools

Setting-out and Marking-out Tools

Saws try-square - sliding bevel - mitre square marking gauge - mortice gauge

hand saws - crosscut saws - ripsaws tenon saws - saws for cutting curves

Planes and Chisels

Hammers, Mallets and Screwdrivers handbrace and bits

Workshop Accessories

Site Accessories $\quad 29$

Water Levels $\quad 30$

3 Joints 32

Basic Woodworking Joints lengthening joints - widthing joints angle joints

4 Portable Powered Hand Tools

5 Woodcutting Machinery

Woodworking Machines Regulations 1971 Il all woodworking machines (general)

The Crosscut Saw

Circular-saw Benches

Woodworking Machines Regulations 1971 III circular-sawing machines - IV multiple ripsawing machines and straight line edging machines

Dimension-saw Benches

Tilting Arbor-saw Bench saw-blade fitting - circular-saw teeth pitch - hook - sharpness angle - clearance angle - top bevel - sharpening teeth packing for saws 
Planing Machines overhead planers

Woodworking Machines Regulations 1971 VI planing machines

Thicknessing Machine

Combined Thicknessing and Surfacing Machine

Morticing Machines hollow chisel morticer - chain morticer

Bandsaws narrow bandsawing machines

Woodworking Machines Regulations 1971 narrow bandsawing machines

Lathes

wood-turning lathe - accessories

6 Ironmongery

Hinges

Locks

Nails

use of nails

Screws

7 Turning Pieces and Centers for Arches

8 Formwork for concrete

In Situ Casting

88

9 Ground Floors
$58 \quad 11$ Doors and Frames

14 Technical Drawing and Geometry 110

Drawing Office Practice (BS 1192: 1969 - Metric) 110 dimension lines - sequence of dimensioning - lettering on drawings - orthographic projection - graphic symbols - representation of materials

Building Drawings basic requirements - setting out drawing paper - construction of angles construction of angles with compasses the protractor - the scale of charts representing objects in drawings - isometric pictorial projections - quadrilaterals - triangles - areas of quadrilaterals - problems - regular polygons - irregular polygons - the circle the ellipse - workshop method for the ellipse Solid Geometry geometrical solids - introduction to orthographic projection - the square pyramid - development of simple roof trusses - simple roof bevels 


\section{Preface}

This book has been written with the City and Guilds of London Institute Syllabuses for the Timber Trades (Part 1) in mind, which are intended to cover the first year of the Carpentry and Joinery and Machine Woodworking crafts.

A portion from each of the practical and theory syllabuses, together with that dealing with science, combine to make an integrated section in which students from both crafts work together, after this each craft goes more deeply into its own speciality. The integrated and the individual sections have not been separated in this book because the author feels that teachers in different colleges will work out their own schemes to cover Part 1 of this new programme. A study of Part 1 will show that very little work is covered in the integrated portion as compared with the sections that the crafts cover separately - a point which some people may regret.

Some teachers may think that the practical and technology parts of the integrated section of Part 1 can be covered in the first term of the year and that the other sections can be spread over the remaining two terms.

Courses with full-time students in the first year of their apprenticeship - who will be expected to sit for their craft examination certificate at the end of their second year at the college - will have to cover Part 1 and also a substantial part of Part 2 in the first year, so that the remaining sections of Part 2 can be covered in the second year, presumably on day release.

Teachers in some colleges with day-release students may feel that the content of Part 2 of the syllabuses presents a formidable task if it is to be covered in the last two years of a three-year course and may therefore decide to include some of the subjects of Part 2 in the first year's work.

In this book, the author is not merely trying to impart knowledge to students, but also to present problems to them to which they should find the answers from other sources, for instance, from their teacher or from their college library. The object of this exercise is to motivate the student to find out for himself.

The teaching of the use of hand tools and woodcutting machinery cannot be accomplished by means of books. The student has to handle the tools himself, get the feel of them and have their proper use demonstrated by an expert. This applies also to machinery; the woodcutting machinist must get to understand these machines thoroughly in the machine shop and handle them under expert supervision.

A book can, however, give details of tools and machines that are not apparent in the workshop. The roles of the workshop and of the machine shop in technical colleges are proficiency in the use of the tools of the trade and the production of work, but the technicalities should be left to the teacher in the classroom and to the author.

It is hoped that future books will cover the two crafts of carpentry and joinery and machine woodworking separately so that students and teachers in those crafts will be able to obtain information on the subject to which they have dedicated a large portion of their working life.

I have been assisted in the compilation of this book by some very useful information and photographs of woodcutting machinery kindly supplied by Wadkin Ltd, of Leicester.

A.B.E. 